Anna Kierzkowska

\title{
CHANGES IN THE AUDIT OF ACCOUNTS REGULATIONS IN POLAND AND THE GUARANTEES OF FREEDOM TO CONDUCT A BUSINESS
}

The commencement of the Act on Freedom of Business Activity ${ }^{1}$ as well as the act - Provisions introducing the law on freedom of business activity ${ }^{2}$ undoubtedly aimed at strengthening the guarantees of freedom to conduct a business, also by means of legal empowerment of the audited entrepreneur against the audit of accounts authorities. As the authors of the act pointed out, its main purpose was to introduce regulations facilitating business activity, with particular reference to strengthening the guarantees of economic liberty and protecting the entrepreneur from excessive audit of accounts. For the first time the act has introduced regulations over the audit of accounts of entrepreneurs. Therefore, this reform was of crucial importance with respect to changing the perception of relations between the state and its citizenry. Though it was made clear that the passed act was incomplete and not able to fulfil expectations, it should be still considered a critical law in terms of perception of auditing business entities. All previously adopted regulations of auditing were of a more general nature and focused only on the financial inspectors and their powers.

The provisions of the Act on The Freedom of Business Activity set up a framework for the actions performed towards the entrepreneurs by the taxation and auditing institutions. The current legal situation empowers the public administration (fiscal) institutions to intervene in the realm of a business' activity as guaranteed by virtue of the Constitution (Art. 20 thereof). Such an intervention may be conducted solely and exclusively to the extent stipulated by the law in force. ${ }^{3}$ In the event of an audit, the basis of such intervention may be the Act on The Freedom of Business

\footnotetext{
1 Ustawa z dnia 2 lipca 2004 r. o swobodzie działalności gospodarczej (t.j. Dz. U. z 2007, Nr 155, poz. 1095 ze $\mathrm{zm}$.) hereinafter referred to as the act on freedom of business activity.

2 Ustawa z dnia 2 lipca 2004 r. - Przepisy wprowadzające ustawę o swobodzie działalności gospodarczej (Dz. U., Nr 173, poz. 1808 ze zm.).

3 Wyrok Wojewódzkiego Sądu Administracyjnego w Lublinie z dnia 4 kwietnia 2008 r. (sygn. akt IS.A./Lu 795/07).
} 
Activity - the defining general principles of taking and conducting an audit of accounts - as well as the provisions of specific acts, as addressed in Art. 77 section 2 of the Act on The Freedom of Business Activity. The Tax Ordinance ${ }^{4}$ shall be considered a specific act in this respect. Such wording of the regulations suggests that the provisions of the Act on Freedom of Business Activity constitute the core of regulations pertaining to the above. In fact, the provisions of both the act on audit of accounts and the tax ordinance act contain far more regulations pertaining to the aforementioned. It consequently addresses the majority of issues concerning relations between entrepreneurs and the financial inspectors. The provisions of any and all specific acts must not be contrary to the stipulations of the Act on Freedom of Business Activity. In a draft amendment to the Tax Ordinance Act, (prepared by the Ministry of Finance), further emphasis of the role of stipulations of the Act on Freedom of Business Activity was suggested. Art. $282 \S 2$ should be amended to "Audit of business accounts shall be conducted pursuant to the principles stipulated in the Act on Freedom of Business Activity". A draft explanation reads that the purpose of the amendment was to explicitly underline the nature of provisions in the Act on Freedom of Business Activity so as to define the general principles applicable to each and every audit of accounts. The introduction of this provision shall not alter the powers of the audited entity, under Art. 77 of the Act on Economic Liberty. It may only facilitate recognised complete legal regulation concerning the rights and obligations of the audited entity towards the audit institution.

Art. 79 shall set forth a requirement to make an actual audit following a previously presented duty card and authorisation for that audit. A similar stipulation can be found also in the Tax Ordinance Act - Art. 284. Both provisions assume that the necessary premise to conduct an audit of accounts is (simultaneously) an authority to carry out an audit and the presentation of a duty card. There is no significant meaning in the order in which the two actions are to be performed, although this creates a discrepancy between the two acts. Nevertheless, the two actions should be performed one immediately after the other, at more or less the same time. In exceptional cases, an audit may be taken solely after presenting a duty card. The Act on Freedom of Business Activity refers to the specific laws as the power to seize control (Art. 79 section 1 thereof). In the event of a financial audit the legal basis shall be Art. 284a of the Tax Ordinance. It shall also authorise an audit within shortest possible time period - three days. In the event of neglecting and non-performance of that duty, both due to the reasons attributable to the audit institution and to actions of the audited entrepreneur, it shall be deemed that the audit has not taken place; any already collected material shall be deemed invalid as accounting evidence. The provisions of the Act on Freedom of Business Activity as well as the stipulations of

4 Ustawa z dnia 29 sierpnia 1997 r. - Ordynacja podatkowa (t.j. Dz. U. z 2005 r., Nr 8 poz. 60 ze zm.) hereinafter referred to as Tax Ordinance. 
the Tax Ordinance Act are therefore flawed. They inadequately address the situation when, for example, due to the absence of the audited entrepreneur, it is impossible to carry out an audit. Neither of the two acts provide for the possibility to suspend an audit. Only in the event of the impossibility of identifying the details of the audited entity, will the three-day term not be binding. In each and every other event, inclusive of the situation when the audited entrepreneur avoids meeting financial inspectors, this term shall be binding.

The provisions of the Act on Freedom of Business Activity shall not prescribe who should be presented with the duty card and authorisation to make an audit. This particular issue is addressed under the Tax Ordinance Act with Art. 284 thereof stipulating that the abovementioned actions shall be carried out affecting the audited entrepreneur personally or another natural person, appointed and duly authorised to represent him during the audit as a result of authorisation submitted to the residing local Head of the Tax Office, under the corporate income tax (Art. 281a thereof).

The authorisation to conduct the audit is usually submitted personally, although the acts do not exclude other forms of submittal. It is generally assumed that personal submittal of the authorisation to conduct the audit may include an element of surprise. However, it should be noted that this element of surprise is not always necessary. The purpose or the circumstances of conducting the audit may justify the need to notify the tax payer of the planned audit in advance. ${ }^{5}$ The regulations pertaining to the above shall be included in the newest draft amendment to Tax Ordinance, which is currently being negotiated. The draft shall include Art. 282b, which transfers the existing power of notification of the intention to conduct an audit. As argued in the draft explanation, the suggested amendments should positively influence public confidence in the financial authorities, they should promote the voluntary disclosure of tax returns and should enable an audited entrepreneur to organize work properly during the audit of accounts. There is no doubt that receiving the notification of the planned audit of accounts shall be of substantial importance in terms of the preparation of proper documents, and shall facilitate the active participation of the audited entrepreneur in all related activities, either personally or by means of his duly authorised representation. It should be noted that the principle of notification in advance of the planned audit of accounts should not be of unlimited nature, in particular due to the possibility of the entrepreneur's disappearance or covering up of the evidence of a committed crime. It should not also influence the pace of operations by the audit of accounts authorities.

Duty cards should be presented and the authorisations should be carried by the financial inspectors. Art. 79 section 3 of the Act on Freedom of Business Activity indicates that personnel changes to the inspectorate shall only be possible 
by means of a separate authorisation. Issuing a new authorisation may not prolong the audit period. When making personnel changes to the inspectorate, the financial authority may not prolong the audit period. The fact that the new inspector must get acquainted with previous findings and the collected documents is of no importance. The provisions of sections 1 and 3 shall have a role of guarantee for the audit related tasks to be performed solely by the duly authorised persons and in the event of audit of accounts, the persons are obliged to keep the identity of the official as well as the financial details confidential, subject to criminal liability.

Art. 79 section 4 of the Act on Freedom of Business Activity defines the minimum items to be included in the authorisation to conduct the audit. These shall be as follows:

1. legal basis,

2. indication of the financial authority,

3. date and place of issuing the authorisation,

4. name and surname of the employee of audit of accounts authority duly authorised to conduct the audit as well as the number of his/her duty card,

5. the company name of the audited entrepreneur,

6. the subjective scope of the audit,

7. indication of the initial date and the anticipated final date of audit,

8. the signature of person giving the authorisation inclusive of his/her position or function,

9. information on rights and obligations of the audited entrepreneur.

The items authorising audit are also stipulated in Art. $283 \S 2$ of the Tax ordinance. Both combinations are very similar to each other. However, it should be noted that the Tax ordinance provides authorisation for inclusion of an indication of the audited entity without defining how it should be indicated. Yet, the Act on Freedom of Business Activity explicitly stipulates that the authorisation should include at least the company name of the audited entrepreneur. The company name in the meaning thereof shall be referred to as name and surname of the audited entrepreneur, if a natural person, company name, if a legal entity, and in the event of partnership also the name and surname of at least one partner - in the view of wording of Art. 79 section 4 as well as Art. 20, 21 and 27 of the Act on Freedom of Business Activity. ${ }^{6}$ 
One of the elements included in the authorisation to conduct a audit shall be indicating the subjective scope of the audit, by means of defining the precise area to be audited. The scope of audit of accounts should be determined quite precisely, within the competence of the audit authority, under the regulations of its both local and material competence. The audit related activities shall not exceed the time and subjective scope provided for in the authorisation. Each and every additional activity to be conducted shall require the issuing of additional authorisation (e.g. in the event when the subjective scope of the audit has been referred to as "the audit consisting in assessment of the correctness of the indicated amount of VAT return for April 2008" the settlements to be audited shall be limited to the related VAT and for a given month (accounting period) only, even though the amount of return results from the amounts brought forward as indicated in the previous months).

It should also be noted that the act, although defining the elements necessary to conduct an audit, shall not define the consequences in the event of existence of defects in the authorisation. This should be considered as its disadvantage.

The Act on Freedom of Business Activity introduced another provision on the principle of conducting audit related activities in the presence of the audited entrepreneur or his duly authorised representative (Art. 80 of the Act on Freedom of Business Activity). It is undoubtedly a provision aiming at the active participation of the audited party in the audit of accounts, without forcing them to participate in the proceedings. The audited entrepreneur shall have a right, but not an obligation, to participate in audit related activities. This principle has been further detailed in the act - the provisions introduce the law on Freedom of Business Activity by means of introducing the duty to notify the audited entrepreneur (or his duly authorised representative) of the place and date of verification of the evidence by two witnesses and expert opinion at least three days in advance. In the legal situation up to 2004, such a notification could have been sent immediately before taking up the proceedings (at the moment the law allows notification of the audited entrepreneur only immediately before an inspection). It should be noted that under the provisions of Art. 80 section 3 of the Act on Freedom of Business Activity, the audited entrepreneur shall have a duty to appoint in writing a person duly authorised to represent them during the audit. In the event of non fulfilment of the duty, the audited entrepreneur shall be liable to fine of over PLN 1,000, under the Code of Offences (Art. 60' $§ 7$ thereof ${ }^{7}$ ).

Tax ordinance, however, provides for the possibility to conduct activities related to audit without the participation of the audited entrepreneur (Art. $289 \S 2$, Art. $285 \S 3$ thereof). It seems that the legal ability to conduct audit related activities without prior notification of the audited entrepreneur shall be contrary to the general 
principle stipulated in Art. 80 the Act on Freedom of Business Activity, unless the premises as provided for in Art. 80 section 2 occur.

In Art. 80 section 1 of the Act on Freedom of Business Activity, the principle has been adopted and in section 2 numerous exceptions have been introduced. And just as the principle of active participation in audit related activities belongs to the rights of the audited entrepreneur, excluding participation shall not be mandatory in the event of those circumstances stipulated in section 2 . The practice shows that the participation of the audited entrepreneur facilitates execution of an audit and shortens its term if statements are submitted and relevant documents are made available; they are also likely to substantially influence the particulars of the post-audit material itself as well as the involvement of the tax payer in order to negate potential charges and to reject those audit findings which are unbeneficial for the taxpayer. The exceptions presented in section 2 are wide ranging. Particular attention should be drawn to item 2 thereof. In fact, any audit may be considered essential to assist proceedings or an investigation conducted against the entrepreneur. The act does not define what kind of proceedings or investigation is to be conducted nor by whom. It is then possible to conduct an audit in relation to already conducted investigation pertaining to a crime under the fiscal penal act - conducted by the tax office. It should be noted, nevertheless, that this exception shall be of crucial importance. It provides for conducting audit related activities against the high risk entities and in relation to the matters requiring rapid operation of the authorities, due to e.g. the risk of losing the evidence. Section 3 item 3 provides, similarly to Art. 82 section 3 item 3 thereof, for the audit of accounts authorities to be granted special powers, subject to specific principles, stipulated in the act, in the event of audits conducted during the course of another audit proceedings.

The Act on Freedom of Business Activity sets forth another obligation on the entrepreneurs - the obligation to keep the audit logbook. The audit authority shall affect entries thereto concerning, in particular, initial and final dates of the audit and its subjective scope. The entries in the logbook should reflect the history of audits of accounts conducted in the company. The analysis of its content may influence the withdrawal by the authorities from conducting the audit, it may also constitute a premise for non conducting another audit at the same business due to the fact that the previous one has not been finalised or that the limits stipulated in Art. 83 of the Act on Freedom of Business Activity have been reached. The provisions of the act shall not define how long the audit logbook as well as the authorisations and audit reports should be kept.

A new solution introduced to the Polish law by means of Art. 82 the Act on Freedom of Business Activity was considered to be of crucial importance. The abovementioned provision introduced some restrictions on simultaneously 
conducting more than one audit of accounts of the entrepreneur. The provision was aimed at protecting the entrepreneurs from the inconvenience resulting from conducting of more than one audit at a time. The binding restrictions, however, shall not be absolute. The adopted principle was later supplemented by the entire catalogue of exclusions, extended in comparison with the catalogue included in Art. 80 section 2 of the Act on Freedom of Business Activity.

In particular, it shall be possible to conduct another simultaneous audit in the event when it is related to the appropriateness of VAT return before affecting such a return. The return dates have been stipulated in the Act on Value Added Tax. ${ }^{8}$ The entrepreneur, depending on the occurring premises and circumstances, shall be entitled to put forward a motion for a tax return for a 25-, 60- and 180-day period. The legislator, by means of introducing the exclusion in item 5 section 2 Art. 80 shall protect the entrepreneur's interest in the event of the necessity to evaluate the correctness of the tax settlements, resulting concurrently in the event of auditing procedures being initiated by the Head of the Tax Office. The doctrine also argues that this stipulation does not discipline fiscal institutions. The lack of such restriction should have a positive impact on decisions to initialise audit measures made by the heads of tax offices, those frequently being the momentous decisions. Such a view may be open to question. The concurrence of two audits at the same time is often incidental and may not have any connection with the needs assessment to conduct the audit which should be based on more rational premises and preceded by thorough analysis of the taxpayer's financial situation. It should also be noted that not implementing audit measures at a given time should not be understood as a retraction by the authority. It may, on the other hand, influence a decision on prolonging the return date, which would be disadvantageous for the entrepreneur. The restriction stipulated in item 6 shows that it shall be possible to take up and conduct the audit concurrently, when it results from the fulfilment of the Community Law on Competition or European Community financial interest protection. This provision shall express the principle of superiority of community law over the national law. In item 7 the legislator introduced the principle under which it shall be possible to conduct a concurrent audit: when it is related to the justification of a VAT tax return, under the regulations on the refund of some expenditure related to the residential buildings of natural persons. ${ }^{9}$

The seven premises of excluding the limitation as stipulated in Art. 82 section 1 of the act are obligatory in nature, i.e. in the event of occurrence of any premise, the authority shall be obliged to withdraw from further proceedings and to arrange a new audit date with the entrepreneur. 
Apart from limits related to the number of audits conducted within one year, another type of limit is stipulated, related to the audit period in one calendar year. When arranging a new audit date the audit of accounts authority should also take into consideration those limits as stipulated in Art. 83, even though the entrepreneur gives his consent for the audit to be conducted. This issue has been addressed in the Ministry of Finance Bulletin of July 12, 2005, ref. no. SP1/768/033-235/1584/04/ AA. ${ }^{10}$

Pursuant to the wording of art. 83 section 1, the audit period of any and all audits conducted by the audit of accounts authorities over the entrepreneurs shall not exceed:

1. One week in relation to sole proprietorships, small and medium enterprises four weeks.

2. In relation to other entrepreneurs - eight weeks.

In section 2, the legislator shall indicate the limitations of the above principle. The catalogue shall include a new audit category in relation to the previous regulations - consisting of the verification of the correctness of the transfer prices agreement's execution. Pursuant to Art. 83 section 2 item 7 of the Act on Freedom of Business Activity, the audit period limitations shall not apply in the event of a decision by the proper authority (Minister of Finance) on the acceptability of the choice and the method applied to determine the transaction price between the affiliated entities. Such a decision would be made on behalf of those entities under separate regulations on transfer prices, - within the scope of the decision's execution.

The limit of audit measures shall be outlined for the authorities. Nevertheless, in the event of a change to the Head of the Tax Office during a calendar year, it should not mean this limit shall be calculated back from the start for the new institution. This issue has been addressed in the aforementioned Ministry of Finance Bulletin. It should be noted, however, that the legislator shall not define what happens in the event of an auditing authority exceeding the limits when conducting audit measures. It seems that exceeding the audit period limits by the authority shall not result in absolute preclusion of the audit outcome and the impossibility to pass an adjudication on the basis of the evidence collected during such an excessive audit. ${ }^{11}$ It should be noted that the financial authorities, with reference to audit period limitations (which under the act shall not apply for audit proceedings), should focus on a particular aspect of the tax payer business in the vast majority, and every audit should be preceded by the thorough financial analysis of their business. It seems that the reform, although mainly focused on the tax payer, should also influence the 
actions performed by the fiscal authorities. The limitations introduced henceforth, despite numerous and wide exceptions, should make the fiscal authorities incline to change their means of operation, in particular their selection of entities to be audited. The decisions on conducting an audit should be carefully thought over and preceded by gathering applicable evidence. It shall be helpful in shortening the time necessary for the performance of particular measures during the audit.

As for the calculating the audit period, it seems that the initial date of the audit should be deemed as of the date indicated in the authorisation, under Art. 79 section 4 item 7 of the Act on Freedom of Business Activity. A more complex issue is the final date of the audit. It seems that the date should be calculated pursuant to the special provision of Art. $291 \S 4$ of the Tax ordinance and the final date of the audit shall be deemed as of the moment of transferring the audit report to the audited entrepreneur. The hindrances to understanding show that the regulations are unfinished. ${ }^{12}$

An instrumentality separate from non application of audit period limits shall be the instrumentality of omission of the audit period to the limits stipulated in Art.83 section 1 of the act. In the event when the outcome of the conducted audit of accounts disclosed a substantial breach of law by the entrepreneur, another audit of the same subjective scope shall be allowed to be conducted in the same calendar year. The legislator excluded the obligation to include the period of such an audit to the total audit periods in a given year. In such an event, considering the explanation included in the Ministry of Finance Bulletin of July12, 2005, and additionally when the audits were conducted by another Head of the Tax Office during the prior audits due to a change in local competence, the period of such an audit shall not be included in the limits as stipulated in section 1 .

To conclude, it should be noted that the Act on Freedom of Business Activity introduced major changes to the exercising of the rights of the audited entity. Defining the general principles of auditing the entrepreneurs under the Act on Freedom of Business Activity has been an innovative solution in Polish legislation. The new regulations aimed at expanding the scope of rights granted to the audited entity, and facilitated the exercising of these rights. However, the aforementioned regulations should not be considered complete, when taking the solutions aimed at both the entrepreneur and the fiscal authorities into consideration. During the course of work over the draft of the act, unenforceable assumptions were adopted. The evaluation of the act is also affected by the fact that it indicates numerous obligations without determining the consequences of their non-performance. Nevertheless, the act is still considered a crucial step forward for the audit of accounts sector, in terms of exercising the freedom of conducting business activity.

12 See also: Pismo Ministerstwa Finansów z 12.07.2005 r., „Biuletyn Skarbowy Ministerstwa Finansów” 2005, No 4, p. 16. 


\section{Streszczenie}

Niniejszy artykuł dotyczy analizy zmian w zakresie przepisów regulujących instytucję audytu księgowego w Polsce, zawartych w ustawie o swobodzie działalności gospodarczej. Podkreśla się w nim pozytywne aspekty reformy, np. zmiana przepisów dotyczących audytu polegająca na zapewnieniu jednostce kontrolowanej większego katalogu praw niż tylko obowiązków. Podejmowane są również negatywne jej strony, w szczególności niekompletność i nieprecyzyjność przepisów, które utrudniają ich stosowanie w praktyce. 